\title{
Effectiveness Of Using The Wondershare Quiz Creator- Based Quiz On Understanding Concept In Calculus I
}

\author{
Farman \\ Program Studi Pendidikan Matematika, Universitas Sembilanbelas November Kolaka, Indonesia \\ Email: farman.math@yahoo.co.id
}

\begin{tabular}{l} 
ARTICLE INFO \\
\hline Article History: \\
Received $: 12-03-2020$ \\
Revised $: 03-05-2020$ \\
Accepted $: 21-05-2020$ \\
Online : $30-05-2020$ \\
Keywords: \\
Quiz, Wondershare Quiz \\
Creator, Understanding \\
concept, Calculus
\end{tabular}

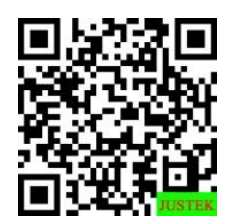

\begin{abstract}
Abstract: This study aims to determine the effectiveness of giving quizzes based on wondershare quiz creators on students' ability to understand concepts in the Calculus I course. This research is an pre-experimental study with one group pretest-posttest design. This study's population were all students of the Sembilabelas November Kolaka University Mathematics Education Study Program in the 2018/2019 academic year. The sample of this research is a saturated sample which is used as an experimental class with a total of 46 students. Data were analyzed descriptively and inferential with paired sample $t$-test with the SPSS application with a significance level of 0.05. The results showed that: (1) the average ability of students' concept understanding was in the medium category with an average of 70.66. (2) Learning by giving quizzes based on wondershare quiz creator is effectively applied in the Calculus I course to support students' conceptual understanding skills.
\end{abstract}

\begin{abstract}
Abstrak: Penelitian ini bertujuan untuk mengetahui efektivitas pemberian kuis berbasis wondershare quiz creator terhadap kemampuan pemahaman konsep mahasiswa pada mata kuliah Kalkulus I. Penelitian ini merupakan penelitian pre-eksperimen dengan desain penelitian one group pretest-posttest design. Populasi penelitian ini adalah seluruh mahasiswa Program Studi Pendidikan Matematika Universitas Sembilabelas November Kolaka tahun akademik 2018/2019. Sampel penelitian ini adalah sampel jenuh yang dijadikan sebagai kelas eksperimen dengan jumlah sebanyak 46 mahasiswa. Data dianalisis secara deskriptif dan inferensial dengan uji-t sampel berpasangan (paired sample $t$-test) dengan aplikasi SPSS taraf signifikansi 0,05. Hasil penelitian diperoleh bahwa: (1) rerata kemampuan pemahaman konsep mahasiswa telah berada pada kategori sedang dengan rarta-rata mencapai 70,66. (2) Pembelajaran dengan pemberian kuis berbasis wondershare quiz creator efektif diterapkan dalam matakuliah Kalkulus I untuk mendukung kemampuan pemahaman konsep mahasiswa.
\end{abstract}

\section{A. LATAR BELAKANG}

Perkembangan pesat di bidang teknologi informasi dan komunikasi saat ini dilandasi oleh perkembangan matematika di bidang aljabar, analisis, teori peluang, teori bilangan, matematika diskrit dan kalkulus. Kalkulus merupakan matakuliah dasar yang wajib dikuasai oleh mahasiswa karena banyak dipakai untuk mempelajari matakuliah lain. Matakuliah kalkulus menjadi prasyarat untuk mengambil matakuliah-matakuliah berikutnya. Akan tetapi hasil evaluasi matakuliah menunjukkan capaian hasil belajar yang 
diperoleh mahasiswa kurang maksimal. Salah satu yang menyebabkan hal ini adalah karena kurang optimalnya kualitas pelaksanaan perkuliahan yang dilaksanakan oleh dosen pengampu. Perkuliahan dilaksanakan dengan hanya mengacu pada struktur kurikulum dan bahan ajar berupa buku teks, tanpa adanya silabus dan SAP standar. Hal ini tentunya menyebabkan persoalan, diantaranya: (a) pemahaman mahasiswa terhadap materi tidak akan optimal, (b) matakuliah tertentu yang berhubungan dengan Kalkulus sebagai matakuliah prasyaratnya akan sulit dipahami, dan (c) masa studi mahasiswa akan bertambah. Selain itu, Mutakin (2015) menyatakan bahwa faktor yang menyebabkan rendahnya pemahaman siswa terhadap matakuliash kalkulus I yaitu terjadinya kesalahan-kesalahan dalam pengerjaan kalkulus 1 karena rendahnya kemampuan dasar mahasiswa dalam penggunaan dasar-dasar operasi matematika, diantaranya operasi bilangan real dan operasi antara suku pada bentuk aljabar.

Upaya peningkatan kualitas pemahaman matakuliah kalkulus harus diimbangi dengan kompetensi para dosen yaitu kualitas pembelajaran dan kualitas penilaiannya. Penggunaan model, metode ataupun cara yang inovatif, kreatif dalam pembelajaran, maka dapat menghasilkan pemahaman dan hasil belajar yang lebih baik pula (Jahring \& Marniati, 2020) (Farman et al., 2019). Penilaian hasil belajar dilakukan untuk mengukur keberhasilan pembelajaran dan mengukur penguasaan materi yang telah diajarkan pada peserta didik. Oleh karena itu seorang guru memerlukan alat evaluasi pembelajaran sebagai instrumen penilaian. Dengan perkembangan teknologi informasi saat ini, penilaian dapat disusun dan dilakukan berbasis ICT. Hal ini bertujuan untuk mengatasi kelemahan alat evaluasi konvensional dengan menggunakan kertas yang masih kurang optimal (Farman, 2020) (Pratiwi, 2016).

Salah satu langkah kegiatan pemecahan isu untuk mengoptimalkan proses pembelajaran kalkulus I yaitu dengan memberikan penilaian formatif berbasis online per pokok bahasan secara intensif. Intensitas penilaian formatif berbasis online per pokok bahasan secara intensif yaitu suatu bentuk pemberian penilaian formatif secara online yang dilakukan setelah suatu materi pokok bahasan tertentu selesai diajarkan dalam satu atau beberapa kali pertemuan. Ide dasar penilaian formatif berbasis online adalah adanya ruang bagi mahasiswa untuk melakukan penilaian diri dan umpan balik terhadap kemajuan pengetahuan mereka saat ini (Rietsche et al., 2017). Selain itu, Hanson \& Mohn juga mengungkapkan bahwa saat in stakeholder mengharapkan penilaian hasil pembelajaran terjadi lebih sering dan lebih ketat, transparan dan dapat diakses (PereraDiltz \& Moe, 2014).

Penilaian formatif dapat menggunakan berbagai bentuk instrumen penilaian diantaranya bentuk kuis. Pemberian kuis adalah suatu cara untuk melatih siswa melakukan refleksi diri terhadap materi yang telah diajarkan. Kondisi ini dapat memfasilitasi siswa dalam mengukur tingkat pemahaman yang telah dicapai. Beberapa hasil penelitian menunjukkan dampak positif penggunaan kuis terhadap pembelajaran. Pemberian kuis dalam pembelajaran membantu siswa dalam memahami konsep (Nguyen \& McDaniel, 2015). Begitu pula sebaliknya, kurangnya pemahaman mahasiswa dalam memahami konsep berakibat pada rendahnya nilai kuis mahasiswa (Fitriani \& Mahsup, 2018). Bahkan selain berpengaruh terhadap motivasi belajar siswa, kuis juga berperangaruh terhadap hasil belajar, minat belajar siswa dan mempertahankan konsep untuk waktu yang cukup lama (Rizal et al., 2016). Penggunaan kuis sebagai assesmen formatif dalam pembelajaran meningkatkan persentase kelulusan mahasiswa (Widjaja, 2018). Penelitian Sari et al. (2018) menyimpulkan bahwa terdapat perbedaan yang signifikan penggunaaan kuis interaktif terhadap kemampuan pemecahan masalah. 
Pada penelitian ini penggunaan kuis secara intensif dilaksanakan berbasis online dengan menggunakan aplikasi wondershare quis creator dan dilaksanakan setiap dua sampai tiga subpokok bahasan materi telah selesai diajarkan. Wondershare quiz creator (WQC) merupakan perangkat lunak untuk membuat soal, kuis atau tes secara offline atau online. Penyusunan soal dengan wondershare quiz creator sangat mudah karena tidak membutuhkan kemampuan bahasa pemrograman untuk mengoperasikannya. (Muchlisin, 2014) menyatakan bahwa penggunaan wondershare quiz creator sangat membantu guru dan siswa dalam kegiatan pembelajaran di kelas. Penggunaan wondershare quiz creator sangat mudah dan memiliki beberapa fasilitas diantaranya umpan balik, pembuatan soal acak, manampilkan skor tes dan pengaturan lainnya.

Hasil penelitian Rahayu et al. (2018) menyatakan bahwa multimedia berbasis wondershare quiz creator layak digunakan dalam pembelajaran matematika sebagai upaya untuk mengatasi kesulitan siswa dalam memahami konsep matematika. Begitu pula penelitian Nasrum (2020) menunjukkan bahwa penggunaan kuis interaktif menggunakan wondershare quiz creator sebagai instrumen evaluasi yang valid dan reliabel dapat digunakan untuk mengukur kemampuan pemahaman konsep kalkulus mahasiswa. Penerapan wondershare quiz creator efektif dari segi waktu dan ekonomis (Meryansumayeka et al., 2018). Melalui penggunaan wondershare quiz creator siswa menjadi lebih mandiri dan percaya diri dalam menyelesaikan soal (Dafitri, 2017). Pengembangan alat evaluasi berbasis wondershare quiz creator dinyatakan valid, praktis dan efektif digunakan dalam pembelajaran (Iqbal et al., 2018)(Kholifah \& Hartanto, 2019).

Penggunaan kuis berbasis wondershare quiz creator pada setiap soal dapat diatur batasan waktu pengerjaan soal. Hal ini akan membuat mahasiswa akan tetap fokus pada soal tes sehingga tidak memiliki waktu untuk meniru jawaban temannya. Dengan demikian kecurangan selama kuis dilaksanakan dapat diminimalisir. Ketika kuis telah dikerjakan maka skor hasil tes siswa akan ditampilkan sehingga kesalahan dapat meminimalisir pengkoreksian, akurat, efektif dan efisien. Selain itu wondershare quiz creator juga menyediakan fasilitas umpan balik atas jawaban yang diberikan siswa, fasilitas keamanan dengan password dan beberapa fasilitas lainnya. Penelitian ini bertujuan untuk mengetahui efektivitas pemberian kuis berbasis wondershare quiz creator terhadap kemampuan pemahaman konsep mahasiswa pada mata kuliah Kalkulus I.

\section{B. METODE PENELITIAN}

Penelitian ini merupakan penelitian pre-experimental dengan menggunakan disain penelitian one group pretest posttest design. Dikatakan pre-experimental karena belum merupakan eksperimen sungguh-sungguh, karena tidak adanya variabel kontrol dan sampel tidak dipilih secara acak (Sugiyono, 2011). Penelitian ini dilaksanakan di Program Studi Pendidikan Matematika FKIP USN Kolaka semester ganjil Tahun Akademik 2018/2019. Teknik sampling yang digunakan adalah purposive sampling yaitu teknik penentuan sampel dengan pertimbangan tertentu, yakni mahasiswa yang memprogramkan matakuliah Kalkulus I dengan jumlah 46 orang. Variabel dalam penelitian ini terdiri dari satu variabel bebas yaitu pemberian kuis berbasis wondershare quiz creator dan satu variabel terikat yaitu pemahaman konsep kalkulus mahasiswa. Instrumen penelitian yang digunakan dalam penelitian berupa tes tertulis bentuk esai. Desain one group pretest posttest design disajikan seperti gambar berikut. 


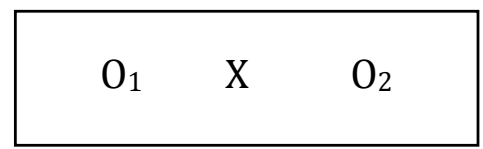

$$
\text { Keterangan: } \begin{aligned}
\mathrm{O}_{1} & =\text { nilai pretest } \\
\mathrm{O}_{2} & =\text { nilai posttest } \\
\mathrm{X} & =\text { treatment (perlakuan) }
\end{aligned}
$$

Gambar 1. Desain one group pretest posttest

Data dalam penelitian ini diperoleh melalui nilai hasil kerja mahasiswa pada tes awal (pretest) sebelum pemberian kuis berbasis wondershare quiz creator pada materi kalkulus I serta nilai hasil mahasiswa pada tes akhir (posttest) setelah pemberian kuis berbasis wondershare quiz creator pada materi Kalkulus I. Penelitian menggunakan dua teknik analisis data yakni analisis deskriptif dan analisis inferensial. Analisis deskriptif dimaksudkan untuk menggambarkan keadaan sampel dalam bentuk persentase, ratarata, standar deviasi, varians, nilai maksimum, nilai minimum, dan untuk menggambarkan tingkat pemahaman konsep mahasiswa dalam bentuk kualitatif. Analisis Inferensial digunakan untuk menguji hipotesis penelitian dengan terlebih dahulu melalui tahapan uji normalitas menggunakan statistik uji Kolmogorov-Smirnov sebagai uji prasyarat untuk melakukan uji hipotesis. Jika data penelitian berdistribusi normal, maka dilakukan uji hipotesis efektivitas model pembelajaran kooperatif terhadap kemampuan pemahaman Kalkulus I, digunakan statistik uji-t sampel berpasangan (paired sample ttest) dengan aplikasi SPSS.

\section{HASIL DAN PEMBAHASAN}

\section{Hasil}

a. Analisis Deskripsitif

Hasil analisis deskriptif data kemampuan pemahaman konsep mahasiswa antara sebelum (pretest) dan setelah (posttest) pemberian kuis berbasis wondershare quiz creator ditunjukkan pada Tabel 1

Tabel 1. Hasil Analisis Statistik Deskriptif Mata kuliah Kalkulus I

\begin{tabular}{cccc}
\hline No & Statistik Deskriptif & Pretest & Posttest \\
\hline 1 & $\mathrm{~N}$ & 46 & 46 \\
\hline 2 & Minimum & 25 & 59,5 \\
\hline 3 & Maksimum & 59,5 & 95,0 \\
\hline 4 & Mean & 49,35 & 70,66 \\
\hline 5 & Standar Deviasi & 11,33376 & 7,67540 \\
\hline 6 & Varians & 128,454 & 58,912 \\
\hline
\end{tabular}

Perbedaan rata-rata kemampuan pemahaman konsep mahasiswa sebelum dan setelah pemberian kuis ditunjukkan pada Tabel 1. Pemberian kuis yang digunakan mampu meningkatkan kemampuan pemahaman konsep mahasiswa dari nilai ratarata 49,35 menjadi 70,66.

Kategori kemampuan pemahaman konsep (Istikomah \& Jana, 2017) pada matakuliah kalkulus I disajikan pada Tabel 2 dan Tabel 3.

Tabel 2. Data Pretest Kemampuan Pemahaman Konsep (KPK)

\begin{tabular}{cccc}
\hline Nilai & Kategori & Frekuensi & Persentase \\
\hline $75 \leq K P K \leq 100$ & Tinggi & 0 & $0 \%$ \\
\hline $50 \leq K P K<75$ & Sedang & 17 & $37 \%$ \\
\hline $25 \leq K P K<50$ & Kurang & 29 & $63 \%$ \\
\hline $0 \leq K P K<25$ & Rendah & 0 & $0 \%$ \\
\hline
\end{tabular}

Tabel 3. Data Posttest Kemampuan Pemahaman Konsep (KPK)

\begin{tabular}{cccc}
\hline Nilai & Kategori & Frekuensi & Persentase \\
\hline $75 \leq K P K \leq 100$ & Tinggi & 11 & $37 \%$ \\
\hline
\end{tabular}




\begin{tabular}{cccc}
\hline $50 \leq K P K<75$ & Sedang & 35 & $63 \%$ \\
\hline $25 \leq K P K<50$ & Kurang & 0 & $0 \%$ \\
\hline $0 \leq K P K<25$ & Rendah & 0 & $0 \%$ \\
\hline
\end{tabular}

Tabel 2 menunjukkan bahwa kemampuan pemahaman konsep pada pretest sebagian besar mencapai kategori kurang baik (\%). Sedangkan pada Tabel 3 menunjukkan bahwa kemampuan pemahaman konsep pada pretest sebagian besar mencapai kategori baik (\%).

b. Analisis Inferensial

Analisis inferensial dilakukan terlebih dahulu dengan uji normalitas menggunakan statistik uji Kolmogorov-Smirnov sebagai uji prasyarat untuk melakukan uji hipotesis. Hasil uji dengan bantuan SPSS disajikan pada Tabel 4

Tabel 4. Hasil Uji Normalitas

\begin{tabular}{llcc}
\hline Statistik & & Pretest & Posttest \\
\hline $\mathrm{N}$ & & 46 & 46 \\
\hline Normal & Mean & 49.3478 & 70.6630 \\
\cline { 2 - 4 } Parameters(a,b) & Std. Deviation & 11.33376 & 7.67540 \\
\hline Most Extreme & Absolute & .110 & .139 \\
\cline { 2 - 4 } Differences & Positive & .086 & .139 \\
\cline { 2 - 4 } & Negative & -.110 & -.116 \\
\hline Kolmogorov-Smirnov Z & .745 & .944 \\
\hline Asymp. Sig. (2-tailed) & .635 & .334 \\
\hline a Test distribution is Normal. & & \\
b Calculated from data. & &
\end{tabular}

Tabel 4 menunjukkan data berdistribusi normal, sehingga dapat dilakukan uji hipotesis dengan menggunakan uji-t sampel berpasangan (paired sampel $t$-test). dengan hipotesis "kuis berbasis wondershare quiz creator efektif digunakan dalam mendukung pemahaman konsep matakuliah Kalkulus I". Hasil uji dengan bantuan SPSS disajikan pada Tabel 5

Tabel 5. Hasil Uji Hipotesis

\begin{tabular}{cccc}
\hline \multirow{2}{*}{ Paired Differences } & \multicolumn{1}{c}{ df } & Sig. (2-tailed) \\
\cline { 2 - 4 } & 13,376 & 45 & 0,000 \\
\hline
\end{tabular}

Tabel 5 menunjukkan nilai t hitung sebesar 13,376 > 2,014 ( $t$ tabel) dan nilai signifikansi Sig. (2-tailed) sebesar 0,00<0,05, artinya Ho ditolak. Dengan ditolaknya Ho dapat disimpulkan bahwa kuis berbasis wondershare quiz creator efektif digunakan dalam mendukung pemahaman konsep matakuliah Kalkulus I pada taraf kepercayaan 95\%.

\section{Pembahasan}

Pemberian kuis merupakan suatu cara untuk melatih mahasiswa melakukan refleksi terhadap materi yang diajarkan sehingga dapat melakukan evaluasi diri atas tingkat pemahaman yang dicapai. Kuis berbasis online ini dilaksanakan setiap dua sampai tiga subpokok bahasan materi telah selesai diajarkan. Hal ini memudahkan siswa untuk memahami materi sedikit demi sedikit sebelum pelaksanaan kuis. Kuis didesain dengan menggunakan aplikasi wondershare quiz creator dengan bentuk soal pilihan ganda dan isian. 
Keefektifan penggunaan kuis terhadap pemahaman konsep terlihat dari hasil analisis data pretest dan posttest melalui analisis deskriptif dan inferensial. Data pretest dan posttest dalam penelitian memberikan gambaran deskriptif adanya peningkatan rata-rata kemampuan pemahaman konsep. Pada pretes, rerata kemampuan pemahamaman konsep berada pada ketegori kurang dan pada posttest berada pada kategori sedang. Sedangkan pada analisis inferensial menunjukkan bahwa hasil uji hipotesis sesuai dengan hipotesis yang diajukan yaitu kuis berbasis wondershare quiz creator efektif digunakan dalam mendukung pemahaman konsep matakuliah Kalkulus I. Efektif yang dimaksud adalah perkuliahan yang telah dilakukan dengan memanfatatkan kuis berbasis wondershare quiz creator dapat memberikan pengaruh positif terhadap pemahaman mahasiswa pada materi Kalkulus I.

Peningkatan rerata seperti yang disajikan pada analisis data menunjukkan bahwa penggunaan kuis berbasis online menggunakan aplikasi wondershare quis creator efektif memfasilitasi kemampuan pemahaman konsep mahasiswa pada matakuliah kalkukus I. Keefektifan terlihat dari perolehan hasil posttest mahasiswa yang menunjukkan kemampuan pemahaman mahasiswa mencapai kategori baik. Hal ini dikarenakan intensitas pelaksanaan kuis dan kemudahan aplikasi wondershare quiz creator yang digunakan. Selain itu mahasiswa menjadi lebih sering belajar, mengerjakan soal latihan dan aktif belajar di kelas untuk mempersiapkan diri dalam mengikuti kuis. Sebagaimana Rizal et al. (2016) mengungkapkan bahwa salah satu keuntungan dari pelaksanaan kuis yaitu memberikan motivasi ekstrinsik bagi siswa karena siswa ingin mendapatkan nilai terbaik sehingga siswa harus berusaha keras dan belajar dengan baik untuk mempersiapkan kuis. Selain itu, juga pelaksanaan kuis interaktif ini dapat meminimalisir kemungkinan mahasiswa untuk melakukan kecurangan. Meryansumayeka et al. (2018) mengungkapkan bahwa kuis interaktif memungkinkan mahasiswa mengerjakan tes dengan jujur karena "memaksa" mahasiswa untuk tetap fokus dalam mengerjakan kuis. Mahasiswa harus fokus karena terdapat batas waktu pengerjaan soal dan soalnya tersusun secara acak. Batas waktu dan lama pengerjaan kuis ditampilkan pada keterangan dan saat mengerjakan kuis.

Dengan demikian pembelajaran dengan pemberian kuis berbasis wondershare quiz creator efektif diterapkan dalam matakuliah Kalkulus I untuk mendukung kemampuan pemahaman konsep mahasiswa. Hal ini ditandai dengan kemampuan mahasiswa dalam menyatakan ulang konsep, mengklasifikasikan objek atau sifat sesuai konsep, memberi contoh dan bukan contoh dari suatu konsep, meyajikan konsep dalam berbagai bentuk representasi, mengembangkan syarat perlu atau syarat cukup, menggunakan prosedur atau operasi tertentu dan mengaplikasikan konsep atau algoritma dalam pemecahahan masalah konsep kalkulus I.

\section{SIMPULAN DAN SARAN}

Berdasarkan hasil pembahasan dari analisa data disimpulkan bahwa: (1) rerata kemampuan pemahaman konsep mengalami peningkatan. Rerata kemampuan pemahamaman konsep pada saat pretest berada pada ketegori kurang $(49,35)$ sedang dan pada posttest berada pada kategori sedang $(70,66)$, (2) Pembelajaran dengan pemberian kuis berbasis wondershare quiz creator efektif diterapkan dalam matakuliah Kalkulus I untuk mendukung kemampuan pemahaman konsep mahasiswa.

Penggunaan kuis berbasis wondershare quiz creator efektif, namun dalam penggunaannya masih memerlukan beberapa aplikasi tambahan untuk akses menggunakan android/smartphone. Aplikasi yang dibutuhkan adalah puffin untuk 
menjalankan output kuis berbasis wondershare quiz creator. Dengan demikian perlu adanya suatu inovasi yang lebih baik dalam evaluasi sehingga dapat berjalan lebih efektif dan efisien.

\section{UCAPAN TERIMA KASIH}

Ucapan terima kasih kepada Program studi Pendidikan Matematika Universitas Sembilanbelas November Kolaka yang telah memberikan kontribusi selama penelitian.

\section{REFERENSI}

Dafitri, H. (2017). Pemanfaatan Wondershare Quiz Creator Dalam Tes Berbasis Komputer. QUERY: Jurnal Sistem Informasi, 1(1), 11.

Farman, F. (2020). Development of Mathematics Learning Design through Problem Posing Approach for Developing Mathematical Reasoning Ability. Proceeding of USN Kolaka-ADRI International Conference on Sustainable Coastal-Community Development, 1(0), 167-174. https://doi.org/10.31327/icusn-adri.v1i0.1158

Farman, F., Chairuddin, \& Hali, F. (2019). Penerapan Model Pembelajaran Kooperatif Student Teams Achievement Division (STAD) Dalam Upaya Meningkatkan Hasil Belajar Matematika Materi Himpunan Siswa Kelas VII1 SMP Negeri 15 Kendari. Jurnal Karya Pendidikan Matematika, 6(2), 82-91. https://doi.org/10.26714/jkpm.6.2.2019.82-91

Fitriani, E., \& Mahsup, M. (2018). Pengaruh Pembelajaran Kooperatif Tipe Jigsaw Untuk Meningkatkan Pemahaman. Justek: Jurnal Sains dan Teknologi, 1(2), 01. https://doi.org/10.31764/justek.v1i2.3541

Iqbal, W. M. G., Fadhilah, R., \& Hadiarti, D. (2018). Pengembangan Alat Evaluasi Berbasis Wondershare Quiz Creator Pada Materi Koloid Kelas Xi Di Sma Koperasi Pontianak. AR-RAZI Jurnal Ilmiah, 6(1). https://doi.org/10.29406/arz.v6i1.937

Istikomah, D. A., \& Jana, P. (2017). Kemampuan Pemahaman Konsep Matematis Mahasiswa Melalui Pendekatan Pembelajaran Saintifik Dalam Perkuliahan Aljabar Matrik. Prosiding Seminar Nasional Pendidikan Matematika Etnomatnesia, 6.

Jahring, J., \& Marniati, M. (2020). Efektivitas Model Pembelajaran Inside Outside Circle (Ioc) Terhadap Hasil Belajar Matematika Siswa SMP. Jurnal Karya Pendidikan Matematika, 7(1), 22-26. https://doi.org/10.26714/jkpm.7.1.2020.22-26

Kholifah, S., \& Hartanto, H. (2019). Development of Wondershare Quiz Creator Multiple Choice Evaluation Tools in Economic Mathematics. Proceedings of the 1st International Conference on Education and Social Science Research (ICESRE 2018). Proceedings of the 1st International Conference on Education and Social Science Research (ICESRE 2018), Semarang, Indonesia. https://doi.org/10.2991/icesre18.2019.64

Meryansumayeka, Virgiawan, M. D., \& Marlini, S. (2018). Pengembangan Kuis Interaktif Berbasis E-Learning Dengan Menggunakan Aplikasi Wondershare Quiz Creator Pada Mata Kuliah Belajar dan Pembelajaran Matematika. Jurnal Pendidikan Matematika, 12(1), 14.

Muchlisin, M. (2014). Implementing Drilling Technique by Using Wondershare Quiz Creator to Improve Students' Reading Ability. Jurnal Pendidikan Humaniora, 2(1), 34-40. https://doi.org/10.17977/jph.v2i1.4441

Mutakin, T. Z. (2015). Analisis Kesulitan Belajar Kalkulus 1 Mahasiswa Teknik Informatika. Formatif: Jurnal Ilmiah Pendidikan MIPA, 3(1). https://doi.org/10.30998/formatif.v3i1.113 
Nasrum, A. (2020). Pengembangan Instrumen Evaluasi Pemahaman Konsep Kalkulus Berbasis Komputer. HISTOGRAM: Jurnal Pendidikan Matematika, 4(1), 78. https://doi.org/10.31100/histogram.v4i1.540

Nguyen, K., \& McDaniel, M. A. (2015). Using Quizzing to Assist Student Learning in the Classroom: The Good, the Bad, and the Ugly. Teaching of Psychology, 42(1), 87-92. https://doi.org/10.1177/0098628314562685

Perera-Diltz, D. M., \& Moe, J. L. (2014). Formative and Summative Assessment in Online Education. Journal of Research in Innovative Teaching, 7(1), 14.

Pratiwi, V., \& Susanti (2016). Pengembangan Alat Evaluasi Pembelajaran Berbasis Ict Menggunakan Wondershare Quiz Creator Pada Materi Penyusutan Aset Tetap. Jurnal Pendidikan, 4(1), 7.

Rahayu, Y. N., Kariadinata, R., Fariansyah, Z., Yaniawati, R. P., \& Sugilar, H. (2018). Development of instructional multimedia for mathematics based on adobe flash and Wondershare quiz creator. IOP Conference Series: Materials Science and Engineering, 434, 012266. https://doi.org/10.1088/1757-899X/434/1/012266

Rietsche, R., Sollner, \& Seufert. (2017). Digital formative learning assessment toolTowards helping students to take ownership of their learning. Twenty-Fifth European Conference on Information Systems (ECIS), Guimarães, Portugal, 11.

Rizal, Muh., Tayeb, T., \& Latuconsina, N. (2016). Efektivitas Penerapan Metode Ekspositori Berbasis Kuis Terhadap Hasil Belajar Matematika Siswa Kelas Viii Mtsn Ma'rang Kabupaten Pangkep. MaPan, 4(2), 171-184. https://doi.org/10.24252/mapan.2016v4n2a2

Sari, D. P., Putra, R. W. Y., \& Syazali, M. (2018). Pengaruh Metode Kuis Interaktif Terhadap Kemampuan Pemecahan Masalah Matematis Mata Kuliah Trigonometri. Jurnal Pendidikan Matematika, 12(2), 10.

Sugiyono. (2011). Metode Penelitian Kuantitatif, Kualitatif dan R\&D. Bandung: Alfabeta.

Widjaja, Y. (2018). Pemanfaatan Kuis Sebagai Asesmen Formatif Dalam Pembelajaran Blok Di Fakultas Kedokteran Universitas Tarumanagara. Jurnal Muara Sains, Teknologi, Kedokteran dan Ilmu Kesehatan, 1(2). https://doi.org/10.24912/jmstkik.v1i2.966 